\title{
The regulatory role of NO-PKG in the cerebellar long-term depression Gabriela Antunes ${ }^{* 1}$ and Erik De Schutter ${ }^{1,2}$
}

\author{
Address: ${ }^{1}$ Computational Neuroscience Unit, Okinawa Institute of Science and Technology, Okinawa 904-0411, Japan and ${ }^{2}$ Theoretical \\ Neurobiology, University of Antwerp, B-2610 Antwerpen, Belgium \\ Email: Gabriela Antunes* - gabriela@oist.jp \\ * Corresponding author
}

from Eighteenth Annual Computational Neuroscience Meeting: CNS*2009

Berlin, Germany. 18-23 July 2009

Published: 13 July 2009

BMC Neuroscience 2009, I0(SuppI I):PI98 doi:I0.II86/I47|-2202-I0-SI-PI98

This abstract is available from: http://www.biomedcentral.com//47/-2202/I0/SI/PI98

(C) 2009 Antunes and De Schutter; licensee BioMed Central Ltd.

\section{Introduction}

Long-term depression (LTD) is a persistent decrease in the efficacy of synaptic transmission that results from the removal of AMPA receptors (AMPARs) from the postsynaptic cellular membrane [1]. In Purkinje cells, LTD can be induced by increasing the postsynaptic calcium concentration $\left(\left[\mathrm{Ca}^{2+}\right]\right)$ using flash photolysis of caged $\mathrm{Ca}^{2+}[2]$, which indicates that other second messengers are not fundamental to the occurrence of LTD. However, recent experimental data pointed out that nitric oxide (NO)cGMP-dependent protein kinase (PKG) pathway can act upstream of $\mathrm{Ca}^{2+}$-signals to regulate $\mathrm{Ca}^{2+}$-induced LTD To gain insights on the biochemical mechanisms involved in this process, we built a computational model to simulate the cerebellar LTD.

\section{Methods}

The model consists of a biochemical network composed by the principal pathways involved in the LTD (NO-PKG, conventional protein kinase $\mathrm{C}$ (PKC) pathway, and mitogen-activated protein kinase (MAPK) pathway). NOPKG pathway has two targets in our model: inositol 1,4,5trisphosphate receptor $\left(\mathrm{IP}_{3} \mathrm{R}\right)$ and $\mathrm{G}$ substrate. PKG phosphorylates $\mathrm{IP}_{3} \mathrm{R}$ causing an increase in its affinity for $\mathrm{IP}_{3}$ [3]. Furthermore, PKG phosphorylates G substrate promoting its binding to protein phosphatase 2A (PP2A), which inhibits its activity. All those biochemical reactions were adapted from previous theoretical works $[2,4,5]$ or were constructed according to experimental data. The model was implemented with the program STEPS.

\section{Results and discussion}

As an initial stage of our work, we simulated LTD induced by flash photolysis of caged $\mathrm{Ca}^{2+}$ and our results show a correlation between the magnitude of LTD and the amplitude of the postsynaptic [ $\left.\mathrm{Ca}^{2+}\right]$, as has been demonstrated previously [1]. To verify the role of NO-PKG pathway in this situation, we simulated the presence of a NO donor (spermine NONOate) while uncaging $\mathrm{Ca}^{2+}$, and our results indicate that NO-PKG pathway decrease the halfmaximum $\left[\mathrm{Ca}^{2+}\right]$ required to induce LTD. We simulated the inhibition of PKG under the same condition, and, during this situation, the alteration in the half-maximum $\left[\mathrm{Ca}^{2+}\right]$ concentration was not observed. Additionally, we were able to inhibit systematically the catalytic action of PKG on $\mathrm{IP}_{3} \mathrm{R}$ and $\mathrm{G}$ substrate, and our results indicate that both phosphorylations are important to the regulatory role of NO-PKG pathway in the cerebellar LTD. We have similar results to LTD induced by synaptic activity. As a conclusion, our results pointed out that although cerebellar LTD can be induced only by increasing postsynaptic $\left[\mathrm{Ca}^{2+}\right]$, NO-PKG pathway modulates this process through its action on $\mathrm{IP}_{3} \mathrm{R}$ and PP2A activity.

\section{Acknowledgements}

We thank Keiko Tanaka and George Augustine for sharing their data.

\section{References}

I. Derkach VA, Oh MC, Guire ES, Soderling TR: Regulatory mechanisms of AMPA receptors in synaptic plasticity. Nat Rev Neurosci $2007,8: 101-113$. 
2. Tanaka K, Khiroug L, Santamaria F, Doi T, Ogasawara H, Ellis-Davies GCR, Augustine G]: $\mathbf{C a}^{2+}$ requirements for cerebellar longterm synaptic depression: role for a postsynaptic leaky integrator. Neuron 2007, 54:787-800.

3. Guihard G, Combettes L, Capiod T: 3':5'-cyclic guanosine monophsphate (cGMP) potentiates the inositol I,4,5-trisphosphate-evoked $\mathrm{Ca}^{2+}$ release inguinea-pig hepatocytes. Biochem J 1 996, 3 1 8:849-855.

4. Doi T, Kuroda S, Michikawa T, Kawato M: Inositol I,4,5-trisphosphate-dependent $\mathrm{Ca}^{2+}$ threshold dynamics detect spikes timing in cerebellar Purkinje cells. J Neurosci 2005, 25:950-96I.

5. Kuroda S, Schweighofer N, Kawato M: Exploration of signal transduction pathways in cerebellar long-term depression by kinetics simulation. J Neurosci 200I, 21:5693-5702.

Publish with Bio Med Central and every scientist can read your work free of charge

"BioMed Central will be the most significant development for disseminating the results of biomedical research in our lifetime. "

Sir Paul Nurse, Cancer Research UK

Your research papers will be:

- available free of charge to the entire biomedical community

- peer reviewed and published immediately upon acceptance

- cited in PubMed and archived on PubMed Central

- yours - you keep the copyright

Submit your manuscript here:

http://www.biomedcentral.com/info/publishing_adv.asp 